\title{
Plasma levels of TGF- $\beta 1$ in homeostasis of the inflammation in sickle cell disease
}

\author{
Lidiane de Souza Torres ${ }^{\text {a,* }}$, Jéssika Viviani Okumura ${ }^{a}$, Danilo Grünig Humberto da Silva ${ }^{a}$, \\ Édis Belini Júnior ${ }^{a}$, Renan Garcia de Oliveira ${ }^{\mathrm{a}}$, Kallyne Kioko Oliveira Mimura ${ }^{\mathrm{b}}$, \\ Clarisse Lopes de Castro Lobo ${ }^{c}$, Sonia Maria Oliani ${ }^{b}$, Claudia Regina Bonini Domingos ${ }^{a}$ \\ ${ }^{a}$ Laboratory of Hemoglobin and Hematologic Genetic Diseases, Department of Biology, Sao Paulo State University (Unesp), Rua Cristóvão Colombo, 2265, São Jose do Rio Preto, \\ SP 15054-000, Brazil \\ ${ }^{\mathrm{b}}$ Laboratory of Imunomorphology, Department of Biology, Sao Paulo State University (Unesp), Rua Cristovão Colombo, 2265, São Jose do Rio Preto, SP 15054-000, Brazil \\ ${ }^{\mathrm{c}}$ Institute of Hematology Arthur de Siqueira Cavalcanti (Hemorio), Rua Frei Caneca, 08, Rio de Janeiro, RJ 20211-030, Brazil
}

\section{A R T I C L E I N F O}

\section{Article history:}

Received 14 October 2015

Received in revised form 20 February 2016

Accepted 23 February 2016

Available online 27 February 2016

\section{Keywords:}

Transforming growth factor

Cytokines

Platelets

Sickle cell anemia

Sickle cell disease

\begin{abstract}
A B S T R A C T
Sickle cell disease (SCD) represents a chronic inflammatory condition with complications triggered by the polymerization of hemoglobin $\mathrm{S}(\mathrm{Hb} \mathrm{S})$, resulting in a series of cellular interactions mediated by inflammatory cytokines, as the transforming growth factor beta (TGF- $\beta$ ), which plays an important role in inflammation resolution. This study assessed the relation between SCD inflammation and the plasma concentration of TGF- $\beta 1$, and also checked the influence of the presence of $-509 \mathrm{C} / \mathrm{T}$ polymorphism in TGFB1 gene on TGF- $\beta 1$ plasma values. The plasma levels of TGF- $\beta 1$ were quantified by ELISA in 115 patients with SCD (genotypes SS, SD-Los Angeles, S $\beta$-thalassemia and SC) and in 58 individuals with no hemoglobinopathies ( $\mathrm{Hb} \mathrm{AA}$ ), as the control group. The $-509 \mathrm{C} / \mathrm{T}$ polymorphism in TGFB1 gene was screened by PCR-RFLP. The correlation between TGF- $\beta 1$ plasma levels and the inflammation was based on its association with the count of platelets, total white blood cells (WBC) and neutrophils in the peripheral blood. Patients with SCD showed plasma levels of TGF- $\beta 1$ higher than the control group, especially the $\mathrm{Hb}$ SS genotype, followed by the group with $\mathrm{Hb}$ SD. Polymorphism investigation showed no interference in the values obtained for the cytokine in the groups evaluated. All SCD groups showed TGF- $\beta 1$ levels positively correlated to the platelets and WBC counts. The original data obtained in this study for SCD support the involvement of TGF- $\beta 1$ in regulating of the inflammatory response and suggest that this marker possibly may become a potential therapeutic target in the treatment of the disease.
\end{abstract}

(c) 2016 Elsevier Ltd. All rights reserved.

\section{Introduction}

Sickle cell disease (SCD) comprehends the group of hemolytic anemia caused by the presence of hemoglobin $\mathrm{S}(\mathrm{Hb} \mathrm{S})$, either in homozygosis (sickle cell anemia), or in association with other hemoglobin variants or thalassemias [1]. Hb $\mathrm{S}$ originates from a point mutation in the beta globin gene (HBB:c.20A > T; rs334) resulting in replacement of glutamic acid for valine in the polypeptide chain, causing structural and biochemical modifications in the hemoglobin molecule [1-3]. Sickle cell anemia is the most common form of the disease, as well as the most severe. The association of $\mathrm{Hb} \mathrm{S}$ with other variants such as $\mathrm{Hb} \mathrm{C}$ (HBB:c.19G > A; rs33930165) and $\mathrm{Hb}$ D-Los Angeles (HBB:c.364G > C; rs33946267) are less frequent and less severe, while its association

\footnotetext{
* Corresponding author.

E-mail address: lidiane.unesp@gmail.com (L.S. Torres).
}

with beta thalassemia results in moderate to severe clinical types, depending on the beta-thalassemia mutation inherited $[1,4]$.

Complications of SCD start with the polymerization of Hb S, erythrocyte sickling, exposure of membrane proteins, hemolytic anemia and ischemia-reperfusion cycles. These recurrent cycles result from vascular occlusion and represent the main stimulus for the inflammatory process, due to endothelial dysfunction, increased vascular inflammation, coagulation activation and oxidative stress created during the restoration of blood flow [5]. Although it plays a protective role in the infection control and promotes tissue repair, the exaggerated inflammatory response can also cause tissue damage. In SCD, inflammation may occur in acute and chronic forms, due to polymerization of $\mathrm{Hb} \mathrm{S}$, which not only results in erythrocyte sickling and intravascular hemolysis, but also a series of cellular interactions mediated by inflammatory cytokines [6].

The transforming growth factor beta (TGF- $\beta$ ) is a pleiotropic cytokine that affects cell proliferation, survival and migration and 
might act as both positive and negative regulator during gene transcription, depending on the target genes and cellular context. It exists in three isoforms: TGF- $\beta 1,2$ and 3 , whereas TGF- $\beta 1$ is the most abundant [7]. TGF- $\beta$ plays an important role in inflammation resolution, since it is associated with the inhibition of immune cells proliferation and the activity suppression of immune system precursor cells. It also acts as a potential inhibitor on $\mathrm{T}$ cells differentiation and apoptosis inducer in B cells, besides participating in the chemotaxis and polarization of macrophages and neutrophils at the inflammation site. On the other hand, it is involved in the releasing of proinflammatory cytokines from neutrophils and in stimulating pro-inflammatory Th17 cells lineage differentiation $[8,9]$.

The TGF- $\beta$ production can be controlled by single nucleotide polymorphisms (SNP) in its gene, such as the $-509 \mathrm{C} / \mathrm{T}$ on TGFB1 (rs1800469), wherein the mutant allele $\mathrm{T}$ is associated with high circulating levels of TGF- $\beta 1$ [10]. The elevation in the TGF- $\beta 1$ levels has been described in sickle cell anemia $[11,12]$ and genetic polymorphisms in $T G F B$, its receptors and members of its activation pathway were related to subphenotypes of the disease, including clinical complications such as myocardial infarction, osteonecrosis, priapism, leg ulcer and pulmonary hypertension [13].

In the present study we built on the observation of the inflammatory condition in SCD patients - genotypes SS, SD-Los Angeles (SD), S/beta-thalassemia ( $\mathrm{S} \beta$-thal) and $\mathrm{SC}$ - based on the association of TGF- $\beta 1$ plasma levels to the total amount of white blood cells (WBC), neutrophils and platelets in the peripheral blood. In addition, we evaluated the relation between the $-509 \mathrm{C} / \mathrm{T}$ polymorphism in the TGFB1 gene and the TGF- $\beta 1$ plasma values.

\section{Methods}

\subsection{Subjects}

The study consisted of 115 SCD patients from the Arthur de Siqueira Cavalcanti Institute of Hematology (Hemorio) in Rio de Janeiro, RJ, Brazil. In order to minimize biases in the analysis, all patients were selected according to exclusion criteria, namely: anti-inflammatory prescription for three weeks prior to sample collection, use of hydroxyurea for up to six months preceding the collection date and blood transfusions carried out in $<60$ days (or $\mathrm{Hb} \mathrm{A}>10.0 \%$ ) [14]. In addition, only individuals over 10 years old were included in the study, since at this age the hemoglobin profile is usually stable [15]. Fifty-eight volunteers, adults of both genders and with normal hemoglobins, without the use of antiinflammatory drugs for three weeks, were part of the control group. The work has the approval by the Research Ethics Committee from Sao Paulo State University (UNESP) under Certificated of Presentation for Ethics Consideration (CAAE) number 08813112.7.0000.5466.

\subsection{Samples, hemoglobin profile and genotyping for SCD}

Peripheral blood samples $(5 \mathrm{ml})$ were collected into tubes containing 5\% ethylenediaminetetraacetic acid (EDTA) as anticoagulant. The hemoglobin migration pattern was evaluated by electrophoresis on cellulose acetate at $\mathrm{pH} 8.6$ [16] and agar-agar gel electrophoresis at $\mathrm{pH} 6.2$ [17]. The red cell morphology was analyzed in light microscope with $40 \times$ objective lens. The quantification of the hemoglobin fractions was performed by high performance liquid chromatography (HPLC) by VARIANT ${ }^{\mathrm{TM}}$ automated equipment (Bio-Rad Laboratories, CA, USA).

To confirm SCD genotype by molecular biology, DNA was extracted from leukocytes by phenol-chloroform method [18] and then subjected to polymerase chain reaction followed by restriction fragment analysis (PCR-RFLP) for identification of mutations that result in hemoglobins S, C, and D-Los Angeles (Table 1) [19].

After genotyping, individuals were separated into four SCD study groups: $\mathrm{Hb} \mathrm{SS}, \mathrm{Hb} \mathrm{SD}, \mathrm{Hb} \mathrm{S} \beta$-thal and $\mathrm{Hb} \mathrm{SC}$; and the control group: Hb AA.

\subsection{TGF- $\beta 1$, platelets and $W B C$}

The $-509 C / T$ polymorphism in the TGFB1 gene was screened by PCR-RFLP using primers sense 5'- CCGCTTCTGTCCTTTCTAGG - 3' and antisense $5^{\prime}$ - AAAGCGGGTGATCCAGATG - 3'. The reaction mix consisted of $1 \times$ reaction buffer, $\operatorname{MgCl}_{2}(5 \mathrm{mM})$, dNTPs $(0.4 \mathrm{mM}), 0.8 \mathrm{mM}$ of each primer, 1 unit of Taq polymerase and $12 \mathrm{ng} / \mu \mathrm{L}$ of DNA. The cycling conditions applied were: $5 \mathrm{~min}$ at $95^{\circ} \mathrm{C}$, followed by 35 cycles of $95^{\circ} \mathrm{C}$ for $30 \mathrm{~s}, 60^{\circ} \mathrm{C}$ for $30 \mathrm{~s}$ and $72{ }^{\circ} \mathrm{C}$ for $30 \mathrm{~s}$, and a final extension of $7 \mathrm{~min}$ at $72{ }^{\circ} \mathrm{C}$. The $406 \mathrm{bp}$ fragment was treated with Bsu36 I restriction enzyme (5'-TNAG G $\left.\downarrow C C-3^{\prime}\right)$, which recognizes the cleavage site in the presence of the normal allele $\mathrm{C}$ and generates two fragments: $223 \mathrm{bp}$ and $183 \mathrm{bp}$. The fragments were visualized on $2.5 \%$ agarose gel stained with ethidium bromide.

The plasma levels of TGF- $\beta 1$ cytokine were evaluated by multiplex instrument LUMINEX xMAP MAGPIX (Millipore Corporation, Billerica, MA, USA). The platelets, WBC and neutrophils count was carried out by flow cytometry and spectrophotometry methods.

\subsection{Statistical analysis}

The chi-square and Fisher's exact tests were applied to the genotypic and allelic frequencies analysis of the -509 C/T (TGFB1) polymorphism in the study groups. The relationship between plasma levels of TGF- $\beta 1$ and the $-509 \mathrm{C} / \mathrm{T}$ polymorphism, as well as TGF$\beta 1$ levels between the SCD and control groups, were evaluated by Student's t-test or Mann-Whitney test, depending on nature of the data (parametric or non-parametric distribution). The TGF- $\beta 1$, platelets, WBC and neutrophils comparisons among the four SCD genotypes were performed using the one-way Anova followed by post hoc Tukey-Kramer. Relations between circulating levels of the markers were evaluated by Pearson correlation test. Simple linear regression analysis was applied to verify the dependence of TGF$\beta 1$, platelets and WBC variables. In all cases, non-parametric data were transformed into square root or base-10 logarithm in an attempt to prioritize the use of parametric tests. The adopted confidence interval was 95\%, with a significance level of $\mathrm{p}<0.05$.

\section{Results}

\subsection{Characterization of the study groups}

After characterization of the 115 samples obtained from patients with SCD, 67 (58.3\%) were from patients with $\mathrm{Hb}$ SS, 30 (26.1\%) with $\mathrm{Hb} \mathrm{SC,} 10$ (8.7\%) with $\mathrm{Hb}$ S $\beta$-thal and eight (6.9\%) with $\mathrm{Hb}$ SD. All 58 control subjects were confirmed with $\mathrm{Hb}$ AA profile. The hemoglobin profile presented by the five study groups are detailed in Table 2.

\section{2. $-509 C / T$ polymorphism frequency and its influence on circulating} levels of TGF- $\beta 1$

The $-509 \mathrm{C} / \mathrm{T}$ polymorphism was investigated in all samples. In the case group we found $39.1 \%$ of the CT genotype and $9.6 \%$ of TT 
Table 1

Initiator oligonucleotides and products generated in the molecular analyzes for identification of SCD genotypes by PCR-RFLP.

\begin{tabular}{|c|c|c|c|c|}
\hline Mutation & Primers & $\begin{array}{l}\text { Size of amplified } \\
\text { sequence }\end{array}$ & Restriction enzyme & Size of the generated fragment for each allele \\
\hline $\begin{array}{l}\mathrm{Hb} \mathrm{S} \\
\quad(H B B: c \cdot 20 \mathrm{~A}>\mathrm{T}) \\
\mathrm{Hb} \mathrm{C} \\
\quad(\text { HBB:c.19G > A })\end{array}$ & $\begin{array}{l}\text { F: 5'-GGCAGAGCCATCTATTGCTTA-3' } \\
\text { R: 5'-ACCTTAGGGTTGCCCATAAC-3' }\end{array}$ & 382 bp & $\begin{array}{l}\text { DdeI }\left(5^{\prime}-\mathrm{C} \downarrow \text { TNAG-3') }\right. \\
\text { BseRI }\left(5^{\prime}-G A G G A G(N)_{\left.10 / 8 \downarrow-3^{\prime}\right)}\right.\end{array}$ & $\begin{array}{l}\text { A: } 201 \mathrm{bp}, 88 \mathrm{bp}, 87 \mathrm{bp} \text { and } 6 \mathrm{bp} \\
\text { T: } 288 \mathrm{bp}, 88 \mathrm{bp} \text { and } 6 \text { bp } \\
\text { G: } 278 \mathrm{bp} \text { and } 104 \mathrm{bp} \\
\text { A: } 382 \mathrm{bp}\end{array}$ \\
\hline $\begin{array}{l}\text { Hb D-Los Angeles } \\
\qquad(H B B: c 364 G>C)\end{array}$ & $\begin{array}{l}\text { F: 5'-TGCCTCTTTGCACCATTCTA-3' } \\
\text { R: 5'-GA CTCCCACATTCCCTTTT-3' }\end{array}$ & 564 bp & EcoRI $\left(5^{\prime}-\mathrm{G} \downarrow\right.$ AATTC $\left.-3^{\prime}\right)$ & $\begin{array}{l}\text { G: } 296 \mathrm{bp} \text { and } 268 \mathrm{bp} \\
\text { C: } 564 \mathrm{bp}\end{array}$ \\
\hline
\end{tabular}

F: Forward; R: Reverse. bp: base pairs.

Table 2

Characterization of the study groups and hemoglobin profile of the samples.

\begin{tabular}{|c|c|c|c|c|c|}
\hline \multirow[t]{2}{*}{ Characteristics } & \multirow{2}{*}{ 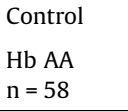 } & \multicolumn{4}{|l|}{ Case } \\
\hline & & $\begin{array}{l}\text { Hb SS } \\
n=67\end{array}$ & $\begin{array}{l}\mathrm{Hb} \text { SD } \\
\mathrm{n}=8\end{array}$ & $\begin{array}{l}\mathrm{Hb} S \beta \text {-thal } \\
\mathrm{n}=10\end{array}$ & $\begin{array}{l}\text { Hb SC } \\
n=30\end{array}$ \\
\hline \multicolumn{6}{|l|}{ Age [years] } \\
\hline $\bar{x} \pm \mathrm{SD}$ & $28.9 \pm 10.3$ & $25.5 \pm 11.6$ & $23.1 \pm 12.3$ & $35.1 \pm 14.4$ & $25.6 \pm 13.8$ \\
\hline Median $\pm \mathrm{IQR}$ & $26.0 \pm 7.0$ & $21.7 \pm 19.0$ & $19.6 \pm 19.6$ & $39.4 \pm 21.3$ & $20.8 \pm 20.7$ \\
\hline \multicolumn{6}{|l|}{ Gender [n (\%)] } \\
\hline Female & $21(36.2)$ & $47(70.1)$ & $3(37.5)$ & $4(40.0)$ & $11(36.7)$ \\
\hline Male & $37(63.8)$ & $20(29.9)$ & $5(62.5)$ & $6(60.0)$ & $19(63.3)$ \\
\hline \multicolumn{6}{|c|}{ Hb profile $(\% ; \bar{x} \pm \mathrm{SD})$} \\
\hline $\mathrm{Hb} \mathrm{A} A_{2}$ & $3.1 \pm 0.3$ & $3.8 \pm 1.1^{\mathrm{a}}$ & $2.7 \pm 0.4^{\mathrm{a}}$ & $5.7 \pm 1.0^{\mathrm{a}}$ & $4.2 \pm 0.4^{\mathrm{a}}$ \\
\hline $\mathrm{Hb} \mathrm{F}$ & $0.3 \pm 0.3$ & $7.0 \pm 4.9^{\mathrm{b}}$ & $6.2 \pm 3.5^{\mathrm{b}}$ & $5.0 \pm 6.4^{\mathrm{b}}$ & $1.5 \pm 1.2^{\mathrm{b}}$ \\
\hline $\mathrm{Hb} \mathrm{S}$ & - & $85.4 \pm 11.3$ & $43.9 \pm 2.9$ & $67.5 \pm 10.2$ & $47.9 \pm 0.9$ \\
\hline Hb D & - & - & $42.7 \pm 1.7$ & - & - \\
\hline $\mathrm{Hb} \mathrm{C}$ & - & - & - & - & $42.2 \pm 2.5$ \\
\hline
\end{tabular}

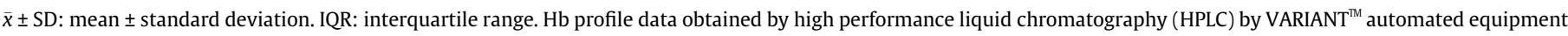
(Bio-Rad Laboratories, CA, USA). Reference values: $\mathrm{Hb} \mathrm{A}_{2}$ (2.5-3.5\%); Hb F (0.0-1.0\%).

a Increased concentrations for $\mathrm{Hb} \mathrm{A}_{2}$ in $\mathrm{SCD}$ groups are due to $\mathrm{Hb} \mathrm{S}$ acetylating (acetylated $\mathrm{Hb} \mathrm{S}$ elutes like $\mathrm{Hb} \mathrm{A}_{2}$ ).

b Increase in $\mathrm{Hb} \mathrm{F}$ concentration is expected to SCD condition.

homozygotes. In the control group, the rate was $51.7 \%$ and $13.9 \%$, respectively. The frequencies between the case and control groups were not statistically different $(p=0.11)$ and there was also no difference between the four genotypes of the disease $(p=0.05)$. The allele frequency observed in the SCD group was 0.7 for the $C$ allele and 0.3 for the $T$ allele, and in the control group was 0.6 and 0.4 , respectively. There was no difference in frequencies between the case and control groups $(p=0.05)$ and within groups with SCD $(p=0.06)$. The data for all groups are shown in Table 3 .

We evaluated the influence of the $-509 \mathrm{C} / \mathrm{T}$ (TGFB1) polymorphism in the plasma levels of TGF- $\beta 1$. For this, due to the small sample size in the $\mathrm{Hb} \mathrm{SD}$ and $\mathrm{Hb} S \beta$-thal genotypes we grouped the polymorphism in two groups: the absence of the mutant allele (CC) and the presence of the mutant allele (CT + TT). We did not observe changes in TGF- $\beta 1$ plasma levels in the presence of the mutant $\mathrm{T}$ allele in control and case groups evaluated (Table 4).

\subsection{Circulating levels of TGF- $\beta 1$, platelets and WBC in $S C D$}

The plasma levels of TGF- $\beta 1$ in the SCD group were quantified and compared to the values presented by the control group. We observed an average increase twice the amount of this cytokine in the plasma of patients (median and interquartile range: $348.0 \pm 374.0 \mathrm{pg} / \mathrm{mL}$ ) compared to the control group (median and interquartile range: $789.0 \pm 1003.0 \mathrm{pg} / \mathrm{mL}$ ) (Mann-Whitney test, $\mathrm{p}<0.01$ ).

Within the SCD genotypes, we observed twice as high values in the homozygous for $\mathrm{Hb} \mathrm{S}(1113.0 \pm 73.6 \mathrm{pg} / \mathrm{mL})$, in relation to $\mathrm{Hb}$ S $\beta$-thal $(499.0 \pm 138.1 \mathrm{pg} / \mathrm{mL})$ and Hb SC $(525.0 \pm \mathrm{p}<0.01)$ groups ( $t$-test, $\mathrm{p}<0.01$ ). We also found higher average values for the $\mathrm{Hb}$ SD group $(957.5 \pm 98.8 \mathrm{pg} / \mathrm{mL})$, comparing with $\mathrm{Hb}$ SC individuals (ANOVA, p < 0.01) (Fig. 1A).

A similar pattern was observed for platelets (Fig. 1B), WBC (Fig. 1C) and neutrophils (Fig. 1D), where the highest values were

Table 3

Genotypic and allelic frequencies for the $-509 \mathrm{C} / \mathrm{T}$ polymorphism in TGFB1 gene.

\begin{tabular}{|c|c|c|c|c|c|c|c|c|c|c|c|c|}
\hline \multirow[t]{2}{*}{ Groups } & \multicolumn{2}{|l|}{$\mathrm{CC}$} & \multicolumn{2}{|l|}{$\mathrm{CT}$} & \multicolumn{2}{|l|}{ TT } & \multirow[t]{2}{*}{$p$} & \multicolumn{2}{|l|}{ C } & \multicolumn{2}{|l|}{$\mathrm{T}$} & \multirow[t]{2}{*}{$p$} \\
\hline & $\mathrm{N}$ & $\%$ & $\mathrm{~N}$ & $\%$ & $\mathrm{~N}$ & $\%$ & & $\mathrm{~N}$ & $\%$ & $\mathrm{~N}$ & $\%$ & \\
\hline Control & 20 & 34.5 & 30 & 51.7 & 8 & 13.8 & 0.11 & 70 & 0.6 & 46 & 0.4 & 0.05 \\
\hline Case & 59 & 51.3 & 45 & 39.1 & 11 & 9.6 & & 163 & 0.7 & 67 & 0.3 & \\
\hline $\mathrm{Hb}$ SS & 31 & 46.3 & 31 & 46.3 & 5 & 7.4 & 0.05 & 93 & 0.7 & 41 & 0.3 & 0.06 \\
\hline $\mathrm{Hb}$ SD & 3 & 37.5 & 2 & 25.0 & 3 & 37.5 & & 8 & 0.5 & 8 & 0.5 & \\
\hline $\mathrm{Hb} S \beta$-thal & 8 & 80.0 & 2 & 20.0 & 0 & 0.0 & & 18 & 0.9 & 2 & 0.1 & \\
\hline $\mathrm{Hb} \mathrm{SC}$ & 17 & 56.7 & 10 & 33.3 & 3 & 10.0 & & 44 & 0.7 & 16 & 0.3 & \\
\hline
\end{tabular}

Case group: includes the four SCD genotypes. Statistical analyzes: chi-square and Fisher's exact tests. Significance level: p < 0.05 . 
Table 4

Plasma levels of TGF- $\beta 1(\mathrm{pg} / \mathrm{mL})$ between the genotypes CC and CT + TT for the $-509 \mathrm{C} / \mathrm{T}$ polymorphism in TGFB1 gene.

\begin{tabular}{lrrrrl}
\hline Groups & \multicolumn{1}{l}{ CC } & N & \multicolumn{1}{l}{ CT + TT } & N & p \\
\hline Control & $457.0 \pm 410.0^{\mathrm{a}}$ & 20 & $313.0 \pm 347.0^{\mathrm{a}}$ & 38 & $0.59^{*}$ \\
Case & $1250.0 \pm 159.9$ & 59 & $1049.0 \pm 93.0$ & 56 & 0.94 \\
Hb SS & $1134.0 \pm 99.7$ & 31 & $1038.0 \pm 91.6$ & 36 & 0.48 \\
Hb SD & $404.0 \pm 28.0$ & 3 & $1013.0 \pm 273.5$ & 5 & 0.22 \\
Hb S $\beta$-thal & $484.3 \pm 163.5$ & 8 & $550.5 \pm 352.5$ & 2 & NP \\
Hb SC & $365.0 \pm 90.3$ & 17 & $715.4 \pm 185.7$ & 13 & 0.18
\end{tabular}

Case group: includes the four SCD genotypes. Data expressed in mean \pm standard error of the mean. Statistical analysis: Student's $t$-test. Significance level: $p<0.05$. NP: statistical analysis not performed due to the low sample size for one of the groups $(\mathrm{n}<3)$.

a Non-parametric data expressed in median \pm quartile range.

* Corresponds to the p value for Mann-Whitney test (nonparametric data).

found for $\mathrm{Hb} \mathrm{SS}$ group comparing to the levels presented by $\mathrm{Hb} \mathrm{S} \beta$ thal and Hb SC groups (ANOVA, $\mathrm{p}<0.01$ ).

\subsection{Relationship between plasma levels of TGF- $\beta 1$ and count of platelets and $W B C$ in $S C D$}

The plasma levels of TGF- $\beta 1$ in SCD showed moderate to strong correlation with the amount of platelets in the blood $(\mathrm{r}=0.56$; $\mathrm{p}<0.01)$. Moderate correlation was observed in $\mathrm{Hb}$ SS group $(\mathrm{r}=0.44 ; \mathrm{p}<0.01)$, while there were strong correlations in $\mathrm{Hb} \mathrm{SD}$ $(\mathrm{r}=0.95 ; \mathrm{p}<0.01), \mathrm{Hb} \mathrm{S} \beta$-thal $(\mathrm{r}=0.81 ; \mathrm{p}=0.02)$ and $\mathrm{Hb} \mathrm{SC}$
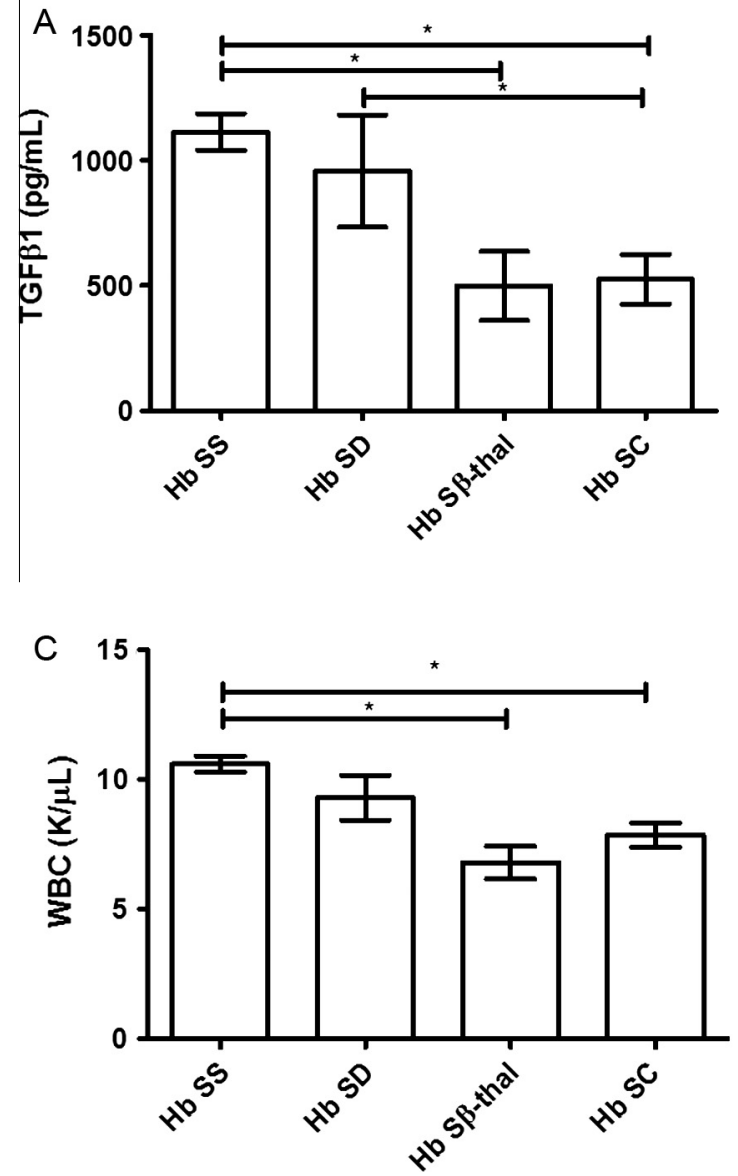

$(\mathrm{r}=0.70 ; \mathrm{p}<0.01)$ groups. Correlations between plasma levels of TGF- $\beta 1$ and neutrophils count were not found in the study groups (Table 5).

Correlation analysis between the number of platelets and WBC were also statistically significant in SCD patients. We observed moderate correlation between platelets and $\mathrm{WBC}(\mathrm{r}=0.61 ; \mathrm{p}<0.01)$ and strong correlation between platelets and neutrophils $(r=0.76$; $\mathrm{p}<0.01$ ). On the other hand, the TGF- $\beta 1$ was moderately correlated to the WBC $(r=40 ; p<0.01)$, but not to the neutrophils $(r=0.40$; $\mathrm{p}=0.12$ ) count. The results of all the correlation analyzes, both for the SCD group and for each genotype, are described in Table 5.

Noticing the association between plasma levels of TGF- $\beta 1$ and the count of platelets and WBC in SCD groups, we applied linear regression analysis in order to verify the dependence between these variables. The case group exhibited a moderately significant ratio between TGF- $\beta 1$ and platelets $\left(r^{2}=0.31, p<0.01\right)$ (Fig. $2 \mathrm{~A}$ ). The ratio between these indices was also found in all four genotypes of SCD, and the relation was weak in $\mathrm{Hb} S S\left(r^{2}=0.10\right.$; $\mathrm{p}<0.01$ ) (Fig. 2B) and $\mathrm{Hb} \mathrm{SC}\left(\mathrm{r}^{2}=0.28, \mathrm{p}<0.01\right)$ genotypes (Fig. 2C), moderate in $\mathrm{Hb} \mathrm{S} \beta$-thal $\left(\mathrm{r}^{2}=0.58 ; \mathrm{p}=0.01\right)$ (Fig. 2D) and strong in $\operatorname{Hb} \operatorname{SD}\left(r^{2}=0.75, p<0.01\right)$ (Fig. 2E). The ratio between TGF- $\beta 1$ and WBC occurred only in the group with $\mathrm{Hb} S \beta$-thal and it was moderate $\left(r^{2}=0.58, p<0.01\right)$.

\section{Discussion}

We describe here the differences between SCD genotypes based on inference of the inflammatory condition, by the dosage of
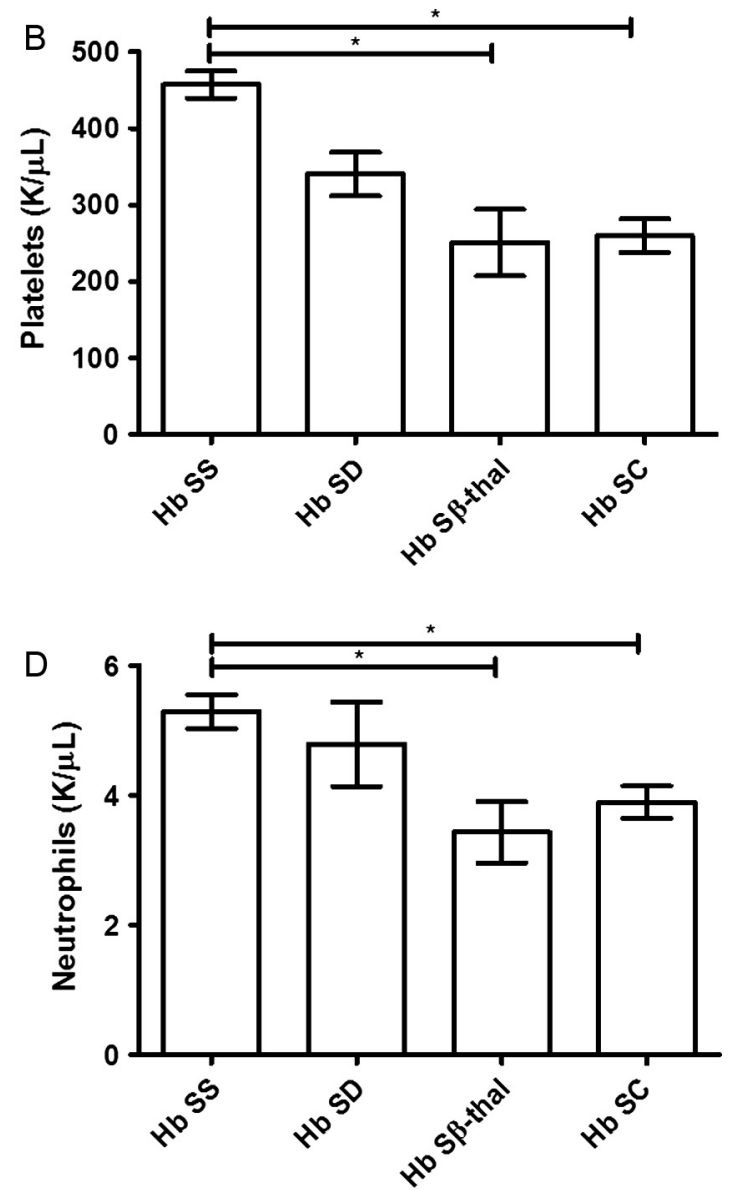

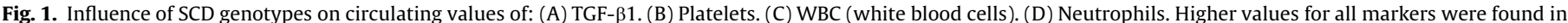

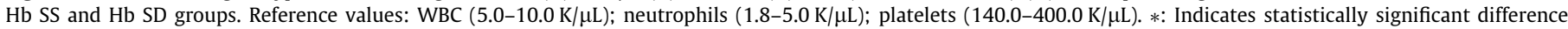
(one-way Anova and post hoc Tukey-Kramer; $\mathrm{p}<0.01$ ). Non-parametric data were transformed in log 10 prior to perform the statistical analysis. 
Table 5

Correlations between the circulating levels of TGF- $\beta 1$, platelets, total WBC and neutrophils in SCD groups.

\begin{tabular}{|c|c|c|c|c|c|c|c|c|c|c|}
\hline \multirow[t]{2}{*}{ Comparisons } & \multicolumn{2}{|c|}{$\begin{array}{l}\text { Case } \\
\mathrm{n}=115\end{array}$} & \multicolumn{2}{|c|}{$\begin{array}{l}\text { Hb SS } \\
n=67\end{array}$} & \multicolumn{2}{|c|}{$\begin{array}{l}\mathrm{Hb} \text { SD } \\
\mathrm{n}=08\end{array}$} & \multicolumn{2}{|c|}{$\begin{array}{l}\mathrm{Hb} S \beta \text {-thal } \\
\mathrm{n}=10\end{array}$} & \multicolumn{2}{|c|}{$\begin{array}{l}\mathrm{Hb} S \mathrm{SC} \\
\mathrm{n}=30\end{array}$} \\
\hline & $\mathrm{r}$ & $\mathrm{p}$ & $r$ & $\mathrm{p}$ & $\mathrm{r}$ & $\mathrm{p}$ & $\mathrm{r}$ & $\mathrm{p}$ & $r$ & $\mathrm{p}$ \\
\hline TGF- $\beta 1 \times$ Platelets & 0.56 & $<0.01$ & 0.44 & 0.01 & 0.95 & $<0.01$ & 0.81 & 0.02 & 0.70 & $<0.01$ \\
\hline TGF- $\beta 1 \times$ Total WBC & 0.40 & $<0.01$ & 0.18 & 0.14 & 0.26 & 0.54 & 0.76 & 0.01 & 0.18 & 0.33 \\
\hline TGF- $\beta 1 \times$ Neutrophils & 0.12 & 0.23 & 0.11 & 0.40 & 0.43 & 0.30 & 0.27 & 0.50 & 0.13 & 0.50 \\
\hline Platelets $\times$ Total WBC & 0.61 & $<0.01$ & 0.35 & $<0.01$ & 0.43 & 0.30 & 0.65 & 0.04 & 0.47 & 0.01 \\
\hline Platelets $\times$ Neutrophils & 0.76 & $<0.01$ & 0.42 & $<0.01$ & 0.57 & 0.15 & 0.29 & 0.41 & 0.17 & 0.37 \\
\hline Total WBC $\times$ Neutrophils & 0.79 & $<0.01$ & 0.80 & $<0.01$ & 0.93 & $<0.01$ & 0.73 & 0.02 & 0.83 & $<0.01$ \\
\hline
\end{tabular}

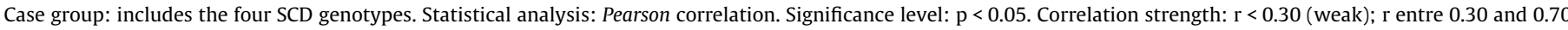
(moderate); $r>0.70$ (strong).

TGF- $\beta 1$ linked to WBC, neutrophils and platelets counts. The evaluated study groups were the four most common genotypes of SCD: $\mathrm{Hb}$ SS, $\mathrm{Hb} \mathrm{SD}, \mathrm{Hb} \mathrm{S} \beta$-thal and $\mathrm{Hb} \mathrm{SC}$. A control group with $\mathrm{Hb} \mathrm{AA}$ was used as reference for TGF- $\beta 1$ dosages and for the effect of $-509 \mathrm{C} / \mathrm{T}$ polymorphism in circulating protein levels.

Although the literature presents studies related to the inflammatory process in sickle cell anemia, this is the first study to considerer the four most common genotypes of SCD. Moreover, this is the first association in SCD between plasma levels of TGF- $\beta 1$ and the main polymorphism involved in the modulation of the TGFB1 gene transcription.

In this study, plasma levels of TGF- $\beta 1$ were higher in SCD when compared to the control group without hemoglobinopathies. It was also noted that, in general, increased plasma levels of TGF- $\beta 1$ was accompanied by WBC count, indicating the presence of an inflammatory response. There is a consensus that SCD courses with chronic inflammatory state characterized by the rise in WBC count and abnormal activation of granulocytes and monocytes $[3,5,20-22]$. The occurrence of clinical manifestations in SCD, in turn, is also related to the circulating WBC count, which reinforces the role of leukocytes in SCD inflammation and pathophysiology. The leukocytosis is usually accompanied by an increase in circulating levels of proinflammatory cytokines that exacerbate the sickling and the vaso-occlusive severity of the disease [6,21].

Genetic associations with inflammation support the involvement of inflammatory pathways in SCD pathophysiology and may explain the phenotypic heterogeneity of the disease [6]. We investigate the influence of $-509 \mathrm{C} / \mathrm{T}$ genetic polymorphism in plasma concentrations of TGF- $\beta 1$ protein in the assessed groups. The polymorphism frequency did not differ between the groups and was similar to the frequencies previously found by our research group and compared to the literature [23].

TGF- $\beta 1$ values were not related to T allele presence for the SCD group or the control group, although the influence of the polymorphism in TGF- $\beta 1$ quantities has already been observed in other populations and diseases [10,24]. According to Grainger and cols., in a study conducted in European population, the $-509 \mathrm{C} / \mathrm{T}$ polymorphism in the promoter region of the gene is associated with high circulating concentrations of TGF- $\beta 1$, due to the change in the consensus binding site of the transcription factor Ying Yang 1 (YY1) [10]. Silverman and cols. evaluated patients with asthma in a case-control study and showed that the $\mathrm{T}$ allele increases the YY1 binding by about 30\%, and the basal promoter function, also by $30 \%$ [24].

As in our study, other authors also found no relationship between circulating levels of TGF- $\beta 1$ and genetic polymorphisms in the regulatory region of TGFB1 [25]. It is known that the inflammatory pathway is complex and many cytokines present pleiotropic activity, so that innumerous factors may be involved in stimulating or inhibiting the production of various cytokines. Possibly due to this complexity, we could not relate the inheritance of only one polymorphism in the gene assessed to the current values of the protein encoded by it. Furthermore, the complexity of pathways involved in the SCD pathophysiology and in modulation of its phenotypic expression can influence the measurements carried out and thus, masking the role of genetic polymorphisms in markers values separately studied.

We observed, however, a relation between plasma levels of TGF$\beta 1$ and the count of platelets in blood of people with SCD. In SCD, platelets circulate in an activated state with abnormal aggregation and increased adhesive properties, due to the expression of adhesion molecules. In addition, platelets also produce significant quantities of inflammatory cytokines and can stimulate endothelial activation [26]. Also in this context, platelets play a pivotal role as mediator of inflammatory response and vascular homeostasis, since they might promote and control the recruitment and adhesion of leukocytes and activation of neutrophils during inflammation [27-29].

TGF- $\beta 1$ is a normal component of alpha granules in platelets and most of the circulating cytokine is derived from the degranulation of these platelets $[30,31]$. In our study, correlation was positive, showing that increased amounts of platelets reflect in higher levels of cytokine in all SCD genotypes. Besides, both TGF- $\beta 1$ and platelets showed positively related to the count of total WBC, indicating their involvement in the inflammatory process. Since platelets contain high concentrations of TGF- $\beta 1$, its count could be used as an indirect measure of the amount of TGF- $\beta 1$ released by platelet degranulation, as previously reported by Assoian and Sporn in cultures of aortic smooth muscle cells [32] and recently demonstrated by Engels and cols in plasma from patients with liver cancer and a control group without the disease [33]. According to the results of this study, we suggest that this ratio could also be used in the inference of TGF- $\beta 1$ levels in SCD.

Although initially identified as a proinflammatory cytokine, due to their neutrophils and macrophages chemoattractant activity, the anti-inflammatory role of TGF- $\beta 1$ has been gaining prominence [9]. In response to tissue damage caused by inflammation, TGF- $\beta 1$ appears to be released by platelets and also by endothelial cells and fibroblasts, maintaining homeostasis and preventing excessive proliferation of immune cells, thus contributing to the resolution of inflammation [8].

Besides attracting macrophages and neutrophils to inflammation sites, TGF- $\beta 1$ promotes the polarization from types M1 to M2 macrophages and from types N1 to N2 neutrophils. Type 1 macrophages present proinflammatory activity, through the production and release of proinflammatory cytokines, such as interleukins (IL-1 $\beta$, IL-6) and tumor necrosis factor alpha (TNF- $\alpha$ ), whereas M2 macrophages are involved in suppressing immune response, through the production of IL-10 and TGF- $\beta$ [34]. Similarly, N1 neutrophils have a higher state of activation and, therefore, a proinflammatory phenotype directed by the release of TNF- $\alpha$ and recruitment of T lymphocytes, for example. On the contrary, N2 neutrophils have less inflammatory activity [35]. 

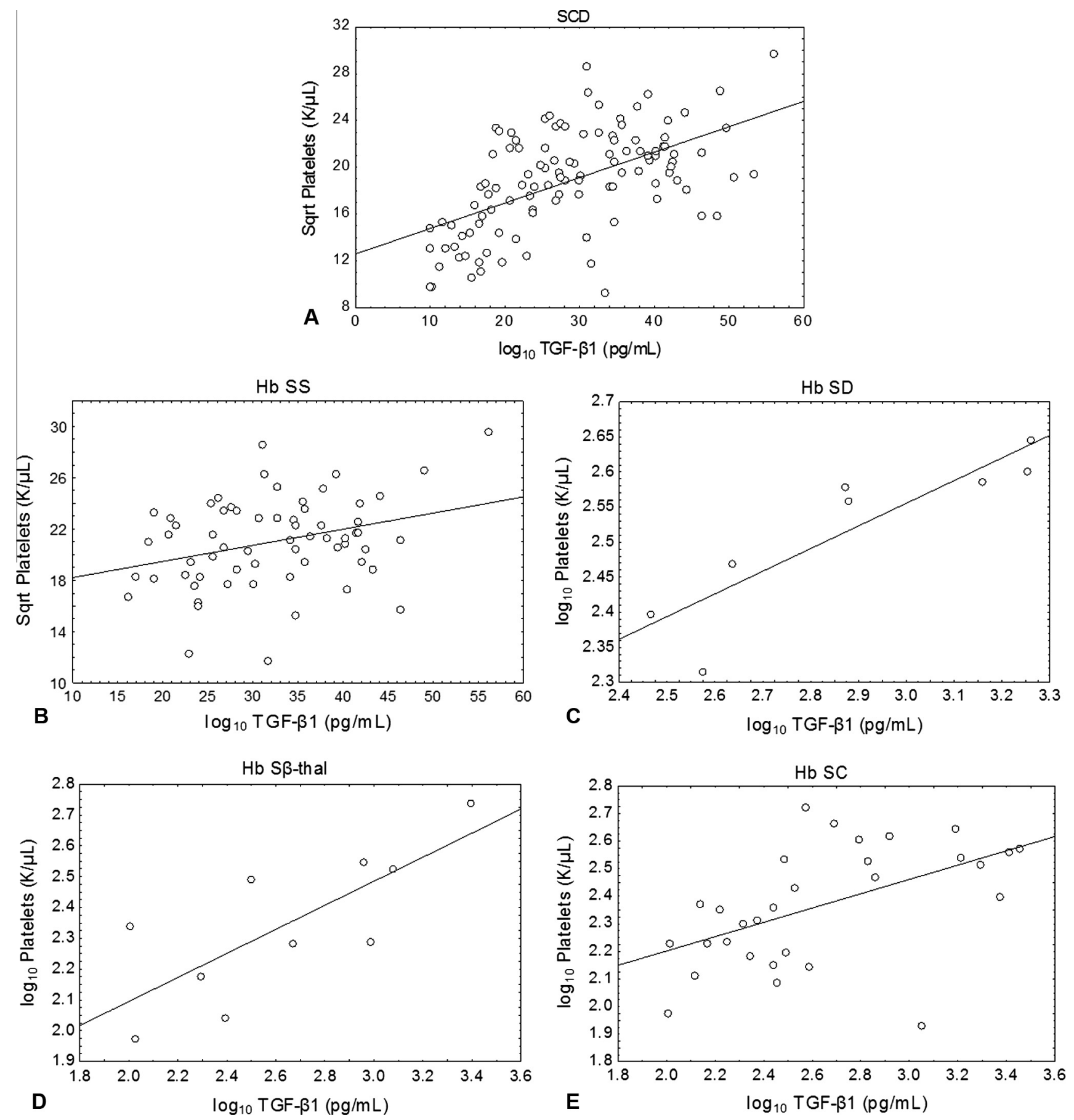

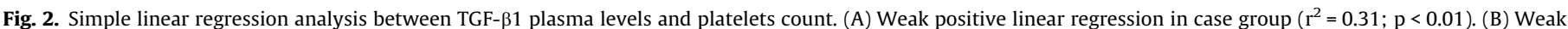

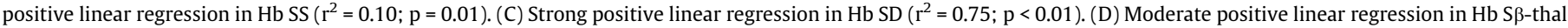
$\left(r^{2}=0.58 ; p<0.01\right)$. (E) Weak positive linear regression in $\mathrm{Hb} \mathrm{SC}\left(r^{2}=0.28 ; p=0.01\right)$. Sqrt: square root.

Based on this, we believe that because of the chronic inflammatory condition in SCD, the levels of TGF- $\beta 1$ are constantly high, especially in cases where the subjects are out of the steady state condition, wherein the hemolytic and vaso-occlusive process is aggravated and culminates in increased inflammatory response.

Among the SCD genotypes, we also found differences in TGF- $\beta 1$ values. Although all SCD genotypes presented high TGF- $\beta 1$ levels, $\mathrm{Hb} \mathrm{SS}$ and $\mathrm{Hb}$ SD groups showed higher averages than the other groups, suggesting that they are the most clinically severe patients. The existence of phenotypic variation among the different genotypes of the disease is well known, and sickle cell anemia is the most severe condition, thus following with greater inflammation and release of pro and anti-inflammatory cytokines, compared to other genotypes, especially the Hb SC genotype $[1,4]$. It is possible that the increased production and release of TGF- $\beta 1$ in these patients is occurring in response to the high level of inflammation and that this release is favorable, suppressing the exacerbation of the inflammatory process.

We note that the $\mathrm{Hb}$ SD group presented similar behavior to $\mathrm{Hb}$ SS genotype in TGF- $\beta 1$ dosages and platelets and WBC counts, different from other genotypes. We believe this result is of importance for determining the hemolytic gravity generated by the association 
of $\mathrm{Hb} \mathrm{D}$ with $\mathrm{Hb} \mathrm{S}[36,37]$. The mutation for $\mathrm{Hb} \mathrm{D}$ occurs in the interaction site between $\mathrm{Hb} \mathrm{S}$ molecules ( $\beta 121$ position) and it is believed that the amino acid change ( $\mathrm{Glu} \rightarrow \mathrm{Gln}$ ) encourages this interaction and consequently the polymerization process, resulting in erythrocyte sickling [31,32]. Adachi and cols. [36] showed that $\mathrm{Hb} \mathrm{S}$ polymerization speed is higher when in association with $\mathrm{Hb}$ D-Punjab. This may explain the possible inflammatory severity of SCD in double heterozygous $\mathrm{Hb}$ SD found in our study.

The immune system regulation by TGF- $\beta 1$ is complex and highly variable, depending on the physiological condition and the types and degrees of differentiation of the cells involved. Because of its multifunctional role and involvement in maintaining tissues homeostasis, clinical applications involving the inhibition or stimulation of the TGF- $\beta 1$ pathway are being investigated, particularly in cases of cancer, fibrosis and autoimmune diseases [8,38].

Among the known effects of TGF- $\beta 1$ in SCD so far in different studies, highlight their involvement in fibrotic processes [39], the inhibition of erythropoiesis $[11,40]$ and inflammatory response [41]. However, in this study, we suggest that its inflammatory role in SCD resides primarily in the maintaining homeostasis, due to its ability to attract and polarize neutrophils and macrophages. Furthermore, the observed relationships between plasma levels of TGF$\beta 1$ and platelet counts are innovative for DF and reinforce the involvement of TGF- $\beta 1$ in regulating the inflammatory response.

Considering the results obtained in this study, showing the involvement of TGF- $\beta 1$ in SCD inflammation and in view of its action already known to control the immune response, TGF- $\beta 1$ might become an important therapeutic target also in SCD. Mechanisms able to blocking the TGF- $\beta$ pathway signaling where its action is mainly proinflammatory and/or promoting its action where the anti-inflammatory role is more expressive could be the key for inflammation treatment in SCD. Future studies will address the mechanisms responsible for TGF- $\beta 1$ activation in SCD.

\section{Conclusion}

In summary, the results presented in this study indicate that the plasma levels of TGF- $\beta 1$ are elevated in SCD, especially sickle cell anemia, the most clinically severe condition. Their levels are related to $\mathrm{WBC}$, evidencing the chronic inflammatory condition triggered by the disease, and associated to the count of circulating platelets, suggesting that increased plasma levels of TGF- $\beta 1$ can be indirectly inferred by increased platelet count in the blood. Because of the strong anti-inflammatory role of the cytokine, the TGF- $\beta 1$ pathway might become an important therapeutic target in the resolution of SCD inflammation. Overall, these data indicate the TGF- $\beta 1$ has an important anti-inflammatory role and represents a potential target for the development of new therapeutic strategies in SCD.

\section{Conflict of interest}

The authors declare no conflict of interest.

\section{Acknowledgements}

The authors thank the FAPESP (Fundação de Amparo à Pesquisa do Estado de São Paulo) for financial support. Process no. 2012/19653-1. In addition, we thank Gabriel Gandolphi for English text review.

\section{References}

[1] M.H. Steinberg, B.G. Forget, D.R. Higgs, et al., Disorders of Hemoglobin: Genetics, Pathophysiology, and Clinical Management, 2nd ed., Cambridge University Press, Cambridge, 2009.
[2] P.S. Frenette, G.F. Atweh, Sickle cell disease: old discoveries, new concepts, and future promise, J. Clin. Invest. 117 (4) (2007) 850-858.

[3] D.C. Rees, T.N. Williams, M.T. Gladwin, Sickle-cell disease, Lancet 376 (9757) (2010) 2018-2031.

[4] M.H. Steinberg, P. Sebastiani, Genetic modifiers of sickle cell disease, Am. J. Hematol. 87 (8) (2012) 795-803.

[5] R.P. Hebbel, Ischemia-reperfusion injury in sickle cell anemia: relationship to acute chest syndrome, endothelial dysfunction, arterial vasculopathy, and inflammatory pain, Hematol. Oncol. Clin. North Am. 28 (2) (2014) 181-198.

[6] C.C. Hoppe, Inflammatory mediators of endothelial injury in sickle cell anemia, Hematol. Oncol. Clin. North Am. 28 (2) (2014) 265-286.

[7] P. Trikha, W.E. Carson 3rd., Signaling pathways involved in MDSC regulation, Biochim. Biophys. Acta 1846 (1) (2014) 55-65.

[8] R.J. Akhurst, A. Hata, Targeting the TGF $\beta$ signalling pathway in disease, Nat. Rev. Drug Discov. 11 (10) (2012) 790-811.

[9] G. Han, F. Li, T.P. Singh, P. Wolf, et al., The pro-inflammatory role of TGF $\beta 1$ : a paradox?, Int J. Biol. Sci. 8 (2) (2012) 228-235.

[10] D.J. Grainger, K. Heathcote, M. Chiano, et al., Genetic control of the circulating concentration of transforming growth factor type beta 1, Hum. Mol. Genet. 8 (1) (1999) 93-97.

[11] H. Croizat, R.L. Nagel, Circulating cytokines response and the level od erythropoiesis in sickle cell anemia, Am. J. Hematol. 60 (2) (1999) 105-115.

[12] B. Keikhaei, A.R. Mohseni, R. Norouzirad, Altered levels of pro-inflammatory cytokines in sickle cell disease patients during vaso-occlusive crises and the steady state condition, Eur. Cytokine Netw. 24 (1) (2013) 45-52.

[13] M.H. Steinberg, Genetic etiologies for phenotypic diversity in sickle cell anemia, Sci. World J. 9 (2009) 46-67.

[14] S.K. Ballas, More definitions in sickle cell disease: steady state v base line data, Am. J. Hematol. 87 (3) (2012) 338.

[15] P. Greer et al., Wintrobe's Clinical Hematology, 13th ed., Lippincott Williams \& Wilkins, Philadelphia, 2014.

[16] A.J. Marengo-Rowe, Rapid electrophoresis and quantitation of haemoglobins on cellulose acetate, J. Clin. Pathol. 18 (6) (1965) 790-792.

[17] F. Vella, Acid-agar gel electrophoresis of human hemoglobins, Am. J. Clin. Pathol. 49 (3) (1968) 440-442.

[18] J. Sambrook, E.F. Fritcsh, T. Manatis, Molecular Cloning: A Laboratory Manual 2nd ed., Cold Spring Harbor Laboratory Press, New York, 1989.

[19] R.K. Saiki, S. Scharf, F. Faloona, et al., Enzymatic amplification of beta-globin genomic sequences and restriction site analysis for diagnosis of sickle-cell anemia, Science 230 (4732) (1985) 1350-1354.

[20] G.J. Kato, R.P. Hebbel, M.H. Steinberg, et al., Vasculopathy in sickle cell disease: biology, pathophysiology, genetics, translational medicine, and newresearch directions, Am. J. Hematol. 84 (9) (2009) 618-625.

[21] M.H. Qari, U. Dier, S.A. Mousa, Biomarkers of inflammation, growth factor, and coagulation activation in patients with sickle cell disease, Clin. Appl. Thromb. Hemost. 18 (2) (2012) 195-200.

[22] E.J. van Beers, Y. Yang, N. Raghavachari, et al., Iron, inflammation, and early death in adults with sickle cell disease, Circ. Res. 116 (2) (2015) 298-306.

[23] L.S. Torres, E. Belini-Júnior, D.G.H. Silva, C.L.C. Lobo, et al., Frequencies of -308G/A (TNFA) and -509C/T (TGFB1) polymorphisms in sickle cell anemia patients from Brazil, Genet. Mol. Res. 12 (4) (2013) 6762-6766.

[24] E.S. Silverman, L.J. Palmer, V. Subramaniam, Transforming growth factor- $\beta 1$ promoter polymorphism C-509T is associated with asma, Am. J. Respir. Crit. Care Med. 169 (2) (2004) 214-219.

[25] E. Rodríguez-Rodríguez, P. Sánchez-Juan, I. Mateo, et al., Serum levels and genetic variation of TGF-beta1 are not associated with Alzheimer's disease, Acta Neurol. Scand. 116 (6) (2007) 409-412.

[26] R. Proença-Ferreira, A.F. Brugnerotto, V.T. Garrido, Endothelial activation by platelets from sickle cell anemia patients, PLoS ONE 9 (2) (2014) e89012.

[27] G. Ed Rainger, M. Chimen, M.J. Harisson, C.M. Yates, et al., The role of platelets in the recruitment of leukocytes during vascular disease, Platelets 26 (6) (2015) 507-520.

[28] K.A. Müller, M. Chatterjee, D. Rath, T. Geisler, Platelets, inflammation and antiinflammatory effects of antiplatelet drugs in ACS and CAD, Throm. Haemost. 114 (4) (2015).

[29] F.W. Lam, K.V. Vijayan, R.E. Rumbaut, Platelets and their interactions with other immune cells, Compr. Physiol. 5 (3) (2015) 1265-1280.

[30] A. Meyer, W. Wang, J. Qu, et al., Platelet TGF- $\beta 1$ contributions to plasma TGF$\beta 1$, cardiac fibrosis, and systolic dysfunction in a mouse model of pressure overload, Blood 119 (4) (2012) 1064-1074.

[31] S. Redondo, J. Navarro-Dorado, M. Ramajo, The complex regulation of TGF- $\beta$ in cardiovascular disease, Vasc. Health Risk Manage. 8 (2012) 533-539.

[32] R.K. Assoian, M.B. Sporn, Type $\beta$ transforming growth factor in human platelets: release during platelet degranulation and action on vascular smooth muscle cells, J. Cell. Biol. 102 (4) (1986) 1217-1223.

[33] E.A. Engels, L. Jennings, T.J. Kemp, et al., Circulating TGF- $\beta 1$ and VEGF and risk of cancer among liver transplant recipients, Cancer Med. 4 (8) (2015) $1252-1257$.

[34] I. Striz, E. Brabcova, L. Kolesar, et al., Cytokine networking of innate immunity cells: a potential target of therapy, Clin. Sci. 126 (9) (2014) 593-612.

[35] R.V. Sionov, Z.G. Fridlender, Z. Granot, The multifaceted roles neutrophils play in the tumor microenvironment, Cancer Microenviron. 8 (3) (2015) $125-158$.

[36] K. Adachi, J. Kim, S. Ballas, et al., Facilitation of $\mathrm{Hb}$ S polymerization by the substitution of Glu for Gln at $\beta 121$, J. Biol. Chem. 263 (12) (1988) 5607-5610. 
[37] L.S. Torres, J.V. Okumura, D.G.H. Silva, C.R. Bonini-Domingos, Hemoglobin DPunjab: origin, distribution and laboratory diagnosis, Rev. Bras. Hematol. Hemoter. 37 (2) (2015) 120-126.

[38] L.J.A.C. Hawinkels, P.T. Dijke, Exploring anti-TGF- $\beta$ therapies in cancer and fibrosis, Growth Factors 29 (4) (2011) 140-152.

[39] G.A. Lutty, C. Merges, S. Crone, S. McLeod, Immunohistochemical insights into sickle cell retinopathy, Curr. Eye Res. 13 (2) (1994) 125-138.
[40] R.M. Böhmer, Cutting edge communication. Reactivation of fetal hemoglobin in adult stem cell erythropoiesis by transforming growth factor- $\beta$, J. Hematother. Stem Cell Res. 12 (5) (2003) 499-504.

[41] J.J. Letterio, A.B. Roberts, Regulation of immune responses by TGF-beta, Annu. Rev. Immunol. 16 (1998) 137-161. 